\title{
The Role of Business Risk and Non Debt Tax Shields on Capital Structure: A study based on Cement Sector in Pakistan
}

\author{
Muhammad Asif Joyo ${ }^{1}$ \\ M.phil Scholar at Institute of Business Management-IoBM \\ Nawaz Ahmad ${ }^{2}$ \\ Assistant Professor at Institute of Business Management-IoBM \\ Ghulam Mustafa Shaikh ${ }^{3}$ \\ Research Associate at Ilma University
}

\begin{abstract}
Objective: The objective of this study is to determine the influence of Business risk and Non Tax shield on Capital structure.

Methodology: This study is based on panel data of 20 companies from the cement sector of Pakistan. Panel regression is applied for statistical analysis.

Conclusion: This study concludes that business risk and non-tax shield has insignificant effect on capital structure (debt to equity ratio), whereas the interest coverage has positive effect on debt to equity ratio.

Policy Implication: As per this study the volatility and business risk involved in the cement sector may have some serious issues if the exports is continuously decline and at same time raising leverage funds may hurt the performance of company
\end{abstract}

Keywords: Business Risk, Financial Leverage, Debt to Equity Ratio, Cement Sector Pakistan

\section{Jel Classification:G12, G14, G32}

*The material presented by the author does not necessarily portray the view point of the editors and the management of the Ilma University - Formerly IBT

1. Muhammad Asif Joyo:

asif.joyo@gmail.com

2. Nawaz Ahmad:

nawaz.ahmad@iobm.edu.pk

3. Ghulam Mustafa Shaikh: iu.gmshaikh@gmail.com

CILMA-JBS is published by the Ilma University - Formerly IBT

Main Ibrahim Hydri Road, Korangi Creek, Karachi-75190, Pakistan. 


\section{INTRODUCTION}

Growth of any sector or firm cannot be possible without the strategic policies and defining capital structure. Whenever, the firms are dealing with capital structure firms have to decide portion of long term debt and its ratio to equity for smoothly run the operations. Meanwhile, firm's raises long term debt may have benefit of reduction in taxes but at the same time this increases the risk of bankruptcy; if the ability of firm is not of repaying the loan on the time. By reducing debt financing and reduction in debts maximize the performance of Korean Chaebol firms; even at times of financial crisis. It further indicates that firms having higher cash flow control take more capital investment (Sung \& Kim, 2017).

Moreover, Firms raising funds for its operations during lower economic growth may create business risk and may directly impact on prices of listed Stock companies. The firms increased their debt with an increase in inflation during the financial crisis hurts the profitability of the firms and causes slowing the growth (Qureshi, Ahsan and Azid, 2017).Whereas, evidence suggests that debt crisis triggers financial reforms, and deterioration of the overall economic environment creates a position where financial reforms are the need of time (Angello, Castro, Jalles and Sousa, 2014).

Furthermore, the debt servicing has become a major component of Pakistan cement Industry cost as even the decrease by three times in the past one year whereas, the effective bank mark up for this sector is still higher than 12 percent(The Nation, 2017). Meanwhile, managers stressed on the importance of capital structure to manage the company financials which requires detailed analysis from various points of views (Brigham and Ehrhardt, 2013).

The difference between the previous study and this work is TIE (Time Interest Earned) and NDTSs (Non Debt Tax Shield) as a moderate on the business risk and TIE while effecting to the leverage of companies. Whereas, the objective of this research is to investigate the effect of TIE and Business risk effects on the Debt to Equity Ratio(DER) and figure out the significance of non-debt tax shield (NDTS) its moderate correlation between TIE and Business risk to DER.

\subsection{Background}

Cement sector is considered one of the major contributors of large-scale manufacturing (LSM), and on the Quantum Index manufacturing (QIM) it contributes 7.19 percent out of average LSM during the July 2016 to March 2017; the average LSM during the period was 5.06 percent. And during the same Fiscal Year (FY) 2017, the fixed investment expenditures increased in particularly cement sector; which is welcome development in an increasing the capacity utilization of the Cement Industry of Pakistan (Pakistan Economic Survey, 2016-2017). On the other hand cement despatches rose by four million tons in March 2017 and achieved full capacity on the strength of robust domestic demand (Business, 2017). Meanwhile, it gives confidence for sustained growth and as well in credit for fixed investments, which is a good sign for a future increase in Pakistan's gross potential to invest in this particular sector(Pakistan Economic Survey, 2016-2017). Despite the fact that, there are substantial investments coming in the cement industry but at the same time decline in 
export pose a business risk to the industry. It is witnessed that export share has dropped from 15 percent to 12 percent this year compared to the FY 2016; whereas, export is considered a significant item which helps the Industry to be remain competitive. In addition to that, Afghanistan the biggest market for Pakistani cement was usurped by cheaper Iranian cement caused decline by 83 percent in March 2017 compared to the same month in 2016; and on monthly average the export is falling by 20 percent year-on-year(Business Recorder, 2017). The increasing demand of cement in domestic market due to "one belt, one road" financed by china spurs construction, and this also caused country's economy has grown at about 5 percent annually since the year 2013 (Bloomberg, 2017). Pakistan is amongst the fastestgrowing construction industry of world and expected to grow on an average of 12 percent annually for the next five years (BMI Research, 2017). And for this the country's cement industry increased its capacity utilization by 88 percent in the 10 months through April 2017 and it is considered the highest in 11 years ( All Pakistan Cement Manufacturer Association, 2017).

Moreover, the boom in domestic industry creates opportunity and as well requires investments and funds for its operational activities and to pay the debts of companies. For this, the Financial Managers needs to make the important decisions related to continuation of operations and funding decisions. Company operated through debt and equity but capital structure signifies the importance while defining composition. The sources of capital structure are included short and long term debt, preferred stock (PS), common stock (CS) and the earned surplus. The company debt decrease the tax and increases the profitability of company and this also prevent the non-tax expense and considered as debt funding which balancing profit from tax debt(Gordon, 2010). The capital structure characteristics tested and results revealed that the financial leverage of Chinese company is significantly lower and shows the tax effect in funding the long term debt(Huang, 2006)

\subsubsection{Problem Statement}

Sustainability of optimal capital structure is one of the major policy issue for policy makers. Excess of debt can benefit in the form of tax shield; however excessive debt also increases risk. This study is designed to investigate the effect of Business risk and Non Tax shield on Capital structure.

\subsubsection{Objective of the Study}

This study aims to find out the role of business risk and non-tax shield in determining the capital structure.

\subsubsection{Scope of Study}

Many practitioners and scholars have already studied on the role of Business risk and significance of tax shield while determining the Debt to equity ratio; but in this study the context is selective cement listed companies of Pakistan stock exchange. 
Journal of Business Studies - JBS Vol.13 Issue.2, December 2017

\section{LITERATURE REVIEW AND HYPOTHESIS DEVELOPMENT}

\subsection{Trade off Theory}

One of the significant problems faced by financial managers is to understand the association amongst capital structure and company's value. Therefore, making choice of managing the fund sources and laying the capital structure is not an easy decision as it is seen, but, it has the important implications on the future operations. According to study, capital structure is not only affected by tax of the company but income tax is also affected by personal income tax (Miller, 1963). Meanwhile the trade theory define "Company will be indebted to a definite debt level where tax saving (tax shields) from additional debt as same as financial difficulty expense (financial distress)". The financial distress referred as bankruptcy cost or it is considered as reorganization and an increase in the agency cost causes the decrease in trustworthiness of a company. The implication of trade-off theory states that the managers are bound to think in trade off framework amongst the financial distress and tax shields while defining the capital structure (Marcus, 2006).

The corporate with the higher profitability can minimize their tax with an increase in the debt ratio (DR) so that the extra debt minimizes the tax. But, rarely finance managers think so that this has significance. Trade off theory defines that company can exchange the advantage of tax from debt finance but with persistence of bankruptcy problem. Tax burden can be curtailed by interest which creates a value for company; whilst company less to pay tax (Brigham and Ehrhardt, 2013). The maximum tax expense of company the more advantages related to debt but profitability and growth relates with the amount of total debt (Salawuand Agboola, 2008).

\subsection{Signaling Theory}

The signaling theory indicates that corporate gives signal through its actions and by making communication (Melewar, 2008). According to research signaling theory is the action has taken by the management of corporate that gives some basic information to investor on company's future growth. Company with better performance may avoid to sale stock and look for fresh funds through other sources including borrowing of loans (Brigham and Ehrhardt, 2013).

The notion of signal was firstly identified in the perspective of job in relation to market product by (Akerlof, 1970) and further this is developed for balancing equation of signal theory, which defines that the worthy company can be illustrious from wicked one by giving signals on product quality (Spence, 1973).

The Signaling theory discovered (Ross , 1977)which defines that when a company wanted to acquire new debt than company issues obligations which gives confidence to the prospective investor about the business prospect and future growth. Whereas, acquiring debt means the inadequacy of cash-flow and also increase in financial distress, but it is the financial manager who will only acquire more debt if it is certain that the company can easily repay the debts and fulfill the responsibilities. The substance of signaling theory is making effort to attract 
stakeholders by creating worth of the company in order to that investor can easily explore the company that carries worthy or wicked value. Signaling theory is a foundation of convincing stakeholders where administration of corporation gives implicit clue to the prospective stakeholder that in what way investor sees the company's growth. To getting the financial resources the valid signal from company is important and for this an asymmetric process needs to be established between management and investor for sharing such information.

\subsection{The relation between TIE and DER}

TIE is also called coverage ratio which measures the obligations with operating profit as well as interest rate (Earnings before Interest and Tax- EBIT) and quantifying the degree to which operating profit get decreased without triggering the failure of repaying the interest on borrowing loans and meets the required obligations. TIE is used to measure the ability of repay interest and loan borrowed by company. If the comparison is made more than one period, and the TIE value goes down by 1.5 creates doubts on company's ability to cover its interest payment. Moreover, if TIE value is less than 1 this means company will be unable to cover interest payments (Sawir, 2008). Therefore, company made plans to meet the requirement of funds and it is strongly affected from interest rates and choices of funds that are raised through obligations and stocks. The NDTSs (Non Debt Tax Shield) causes' thrift tax and it is derived from the use of debt, and this also can be used as a source of capital in order to ease debt and serves as decline factor as well tax shield but besides that this one also considered as depreciation factor. So larger the depreciation, the company will have thrift income tax and cash flow. Whereas study suggests that NDTSs has no association with the total debts and it has substantial relation with both short term and long term debt. There are significant dissimilarities between the debt ratios including short and long term. Meanwhile, NDTSs has positive association with short term obligations and negative association with long term debt which cause thrift tax (Song, 2005). This study is effort to find out the association between NDTS and TIE on dependent variable debt to equity ratio (DER). Based on the above postulate the following hypotheses are formulated:

$\mathrm{H}_{1}$ : Coverage ratio (TIE) has significant impact on Capital Structure (DER).

\subsection{The relation between TIE (Time Interest Earned), Business Risk (BRISK) and Non Debt Tax Shield (NDTSs) to DER (Debt to Equity Ratio)}

Business risk is precarious and usually faced by companies while running its operations. A good company always balances its financial position through debt and other sources of funding. In addition to that, a study was conducted on the determination of capital structure by using moderation variable to find out the size of company (Jaggi and Gul, 1999). Studied the associations between Non Debt tax shield (Kolay et al. (2011)and tax debt by using moderate variable Non debt tax shield (NDTSs) called 'Tax spread' measured by the difference between tax cost and paid tax and it is also found that there is significantly positive relation between leverage and size of Non debt tax shield, whereas the study concluded that company has debts may have alternate option to reduce tax income (Graham , 2000). 
On the basis of capital structure the theory revealed that country's having relatively higher leverage generate institution income tax and also has positive effect on marginal tax cost. Besides, findings suggested that NDTS has positive impact on the capital structure in non-tax economy. Meanwhile it is also concluded that there is no significant impact when economy is with tax. Furthermore, findings suggest that leverage systematically associate with the size of firm, guarantees and profitability (Barakat and Rao, 2012). Based on the above explication following hypotheses are formulated:

$\mathrm{H}_{2}$ : Business risk has significant impact on Capital Structure (DER)

$\mathrm{H}_{3}$ :The Non Debt Tax Shield (NDTS) has significant impact on Capital Structure (DER)

\section{METHODOLOGY}

\subsection{Population and Sample Size}

The sample size for the study consists of 100 observations of cement sector of Pakistan for the period of 5 years from 2012-2016 including 20 companies. Purposive sampling technique is used based on the objective of the study to determine the ability to pay interest on financial leverage.

\subsection{Variables Measurement}

Variables of the study are illustrated below

\subsection{Capital Structure (DER)}

Capital Structure is measured by Debt to Equity Ratio (DER). The DER is the ratio of debt over equity calculating the size of assets financed by the dept; in this study it is observed that internal source of financing being used for mega projects which affects the performance of the companies for the long term benefits of shareholders (Kasmir, 2012).This concludes that higher the value of DER increases the burden on the shareholders.

$$
D / E_{-} \text {Ratio } \equiv \frac{\text { total_debt }}{\text { total_Equity }}
$$

\subsection{Non debt tax shields (NDTS)}

Non debt tax shields (NDTS) from depreciation and amortization, considered as cash flows from inside source of the company, which leads to the reduced induction of financing from the debt(Princen, 2012).

$$
\text { NDTS }=\frac{\text { Total__Depreciation }}{\text { Total_Assets }}
$$

\subsection{Tie}

TIE is the comparison between net profit interest and tax with cost of financing, this ratio can be used to determine the ability to pay the debt and interest, and more the value of 
the TIE increases the possibility of the company to pay its interest and debts (Sawir A. , 2008). Also called coverage ratio with reference the ability to cover the interest and debt payment over the time period.

$$
T I E=\frac{E B I T}{\text { InternalCost }}
$$

\subsection{Business Risk}

Business risk consists of financial leverage risk and operating leverage risk according to (Sahudin, Mehmood, Ismail, Paradi, Aziz, \& Sahudin, 2011)

$$
B u \sin e s s_{-} R i s k=\partial \frac{E B I T}{\text { Total_Assets }}
$$

\section{DATA ANALYSIS TECHNIQUE AND EMPIRICAL MODEL}

Data collected from the annual reports of companies except the market prices of 20 selected companies. The selected panel data of companies regressed through the statistical technique panel regression. For estimating the effects and testing the formulated hypothesis following model developed for finding the significance of study:

Model:

$Y=\beta_{0}+\beta_{1} * T I E+\beta_{2} * B R I S K+\beta_{3} * N D T S+\varepsilon$

$\mathrm{Y}=$ Debt to equity ratio

TIE $=$ Time interest earned

BRISK $=$ Business risk

NDTS $=$ Non debt tax shields

$\varepsilon=$ Error term

$\beta_{0}=$ constant

$\beta 1, \beta 2, \beta 3=$ Coefficients of independent variables

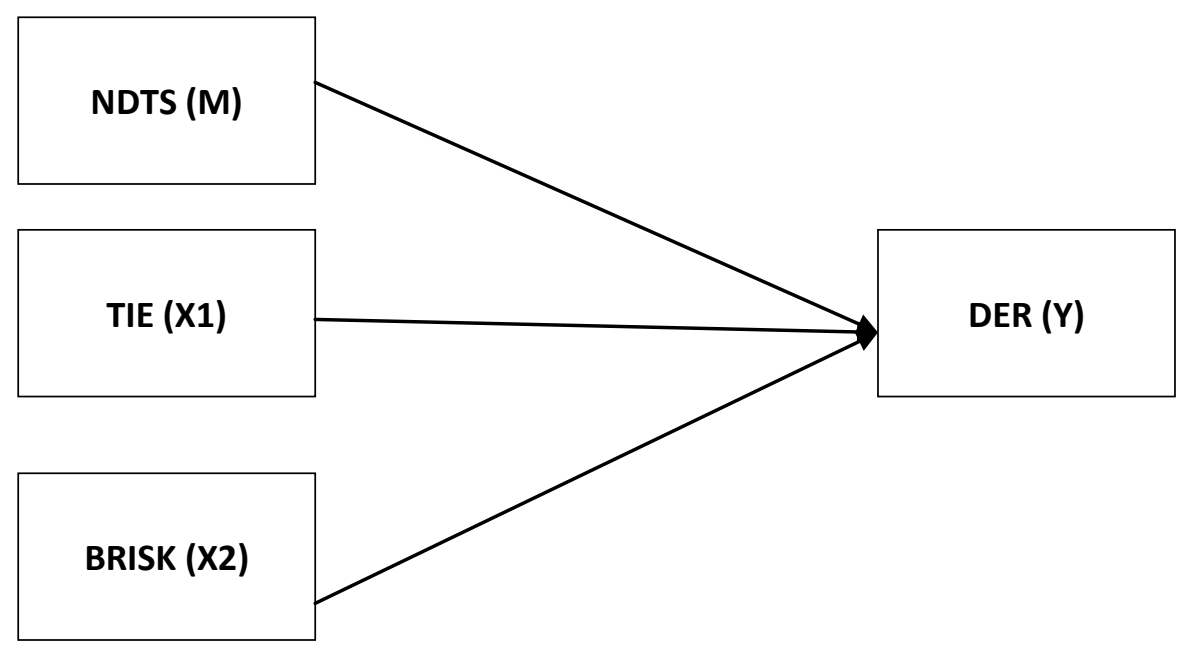




\subsection{Statistical Result}

The table 1 shows the results of panel least square. Standard error of TIE is smaller which indicates the companies have profit income less than one compared with the interest cost. Moreover, this study confirming that negative coefficient of TIE means the companies are not earning enough to pay off its liabilities. From Creditors point of view negative relation with debt to equity ratio is not positive sign because this increases interest income for lenders. And the companies having weak ratio may face difficulties in raising capital in future for their operations. (Suratno, Djaddang, \& Ghozali, 2017). TIE and Business risk (i.e. BRISK) have significant association with debt to equity because the sig value in Table 1 is less than 5\% level of significance. Moreover, NDEBTTAXSHIELD shows insignificant association with debt to equity. The $\mathrm{R}$ squared value of 0.5064 indicated that more than $50 \%$ of variation in debt to equity (i.e. dependent variable) has been explained by these three predictors.

Table 1: Panel Regression Results

\begin{tabular}{|c|c|c|c|c|}
\hline \multicolumn{5}{|c|}{$\begin{array}{l}\text { Dependent Variable: DEBTEQUITY } \\
\text { Method: Panel Least Squares } \\
\text { Date: } 08 / 21 / 17 \text { Time: } 22: 13 \\
\text { Sample: } 20122016 \\
\text { Periods included: } 5 \\
\text { Cross-sections included: } 20 \\
\text { Total panel (balanced) observations: } 100\end{array}$} \\
\hline Variable & Coefficient & Std. Error & t-Statistic & Prob. \\
\hline $\begin{array}{l}\text { NDEBTTAXSHIELD } \\
\text { TIMEEARNEDINTEREST } \\
\text { BRISK } \\
\text { C }\end{array}$ & $\begin{array}{l}-0.000158 \\
-0.005653 \\
0.024605 \\
0.322824\end{array}$ & $\begin{array}{l}0.000167 \\
0.000775 \\
0.005520 \\
0.016805\end{array}$ & $\begin{array}{l}-0.944586 \\
-7.296509 \\
4.457313 \\
19.20991\end{array}$ & $\begin{array}{l}0.3472 \\
0.0000 \\
0.0000 \\
0.0000\end{array}$ \\
\hline $\begin{array}{l}\text { R-squared } \\
\text { Adjusted R-squared } \\
\text { S.E. of regression } \\
\text { Sum squared resid } \\
\text { Log likelihood } \\
\text { F-statistic } \\
\text { Prob(F-statistic) }\end{array}$ & $\begin{array}{l}0.506468 \\
0.491046 \\
0.119320 \\
1.366775 \\
72.74196 \\
32.83882 \\
0.000000\end{array}$ & \multicolumn{2}{|c|}{$\begin{array}{l}\text { Mean dependent var } \\
\text { S.D. dependent var } \\
\text { Akaike info criterion } \\
\text { Schwarz criterion } \\
\text { Hannan-Quinn criter. } \\
\text { Durbin-Watson stat }\end{array}$} & $\begin{array}{l}0.368055 \\
0.167253 \\
-1.374839 \\
-1.270632 \\
-1.332665 \\
0.397652\end{array}$ \\
\hline
\end{tabular}

\subsection{Model Hypothesis Testing}

To test the hypotheses of the study, we compare the random and fixed effect model to decided which model is to choose for hypotheses.

Fixed Effects Statistical Models:

$$
D E_{i t}=\alpha_{i}+\beta_{1} N T D S_{i t}+\beta_{2} B_{R I S K}+\beta_{3} T I E_{i t}+\varepsilon_{i t}
$$

Where:

$$
\alpha_{i}=\alpha+F_{i}
$$

here $F i$ is the unobserved variables 
In the fixed effect model also known as Least Squares Dummy Variable Model" (LSDVM), we assume that there are unique attributes of individuals firms that are not the results of random variation and that do not vary across time. It is adequate if we want to draw inferences only about the examined individuals.

\section{$\underline{\text { Random Effect Statistical Models: }}$}

$$
D E_{i t}=\alpha+\beta_{1} N T D S_{i t}+\beta_{2} B R I S K_{i t}+\beta_{3} T I E_{i t}+v_{i t}
$$

Where

$$
v_{i t}=F_{i}+\varepsilon_{i t}
$$

Where $F i$ is the unobserved or hidden variables in the model added to the error term $\varepsilon$.

In the random effect model it is assumed that there are unique or random, time invariant (i.e. constant) attributes of individuals that are the results of random variation and do not correlate with the individual regressors.

The Correlated Random Effects - Hausman Test is applied to compare or choose between random and fixed effect model.

Hypothesis for Hausman test:

$$
\begin{aligned}
& H_{0}: \operatorname{Cov}\left(X_{i}, U_{i}\right)=0_{\text {or FEM is efficient or consistent i.e. there is random effect }} \\
& H_{1}: \operatorname{Cov}\left(X_{i}, U_{i}\right) \neq 0 \text { or } \text { FEM is efficient or consistent i.e. there is random effect }
\end{aligned}
$$

\begin{tabular}{|c|c|c|}
\hline \multicolumn{3}{|c|}{$\begin{array}{l}\text { Correlated Random Effects - Hausman Test } \\
\text { Test cross-section random effects }\end{array}$} \\
\hline Test Summary & $\begin{array}{l}\text { Chi-Sq. } \\
\text { Statistic }\end{array}$ & Chi-Sq. d.f. Prob. \\
\hline Cross-section random & 13.336236 & 0.0040 \\
\hline
\end{tabular}

Table 2:Correlated Random Effects - Hausman Test of comparison between REM and FEM

The probability value (0.0040) in the above table is less than $5 \%$ level of significance; therefore we reject the null hypothesis and can conclude that fixed effect model is appropriate and consistent.

Because hausman test suggested that fixed effect is consisting, therefore, we will test our hypothesis on fixed effect model. 
Table 3: Fixed effect model results

\begin{tabular}{|c|c|c|c|c|}
\hline \multicolumn{5}{|c|}{$\begin{array}{l}\text { Dependent Variable: DEBTEQUITY } \\
\text { Method: Panel Least Squares } \\
\text { Date: 08/21/17 Time: } 10: 50 \\
\text { Sample: } 20122016 \\
\text { Periods included: } 5 \\
\text { Cross-sections included: } 20 \\
\text { Total panel (balanced) observations: } 100\end{array}$} \\
\hline \multicolumn{3}{|c|}{ Coefficient Std. Error } & t-Statistic & Prob. \\
\hline \multirow{3}{*}{$\begin{array}{l}\text { NDEBTTAXSHIELD } \\
\text { BRISK } \\
\text { TIE } \\
\text { C }\end{array}$} & -0.000113 & 0.000207 & -0.544406 & \multirow{4}{*}{$\begin{array}{l}0.5877 \\
0.2488 \\
0.0032 \\
0.0000\end{array}$} \\
\hline & 0.009200 & 0.007917 & 1.162057 & \\
\hline & -0.005719 & 0.001877 & -3.047494 & \\
\hline $\mathrm{C}$ & 0.451187 & 0.038545 & 11.70539 & \\
\hline \multicolumn{5}{|c|}{ Effects Specification } \\
\hline \multicolumn{5}{|c|}{ Cross-section fixed (dummy variables) } \\
\hline \multirow{7}{*}{$\begin{array}{l}\text { R-squared } \\
\text { Adjusted R-squared } \\
\text { S.E. of regression } \\
\text { Sum squared resid } \\
\text { Log likelihood } \\
\text { F-statistic } \\
\text { Prob(F-statistic) }\end{array}$} & \multirow{7}{*}{$\begin{array}{l}0.843864 \\
0.799253 \\
0.074937 \\
0.432400 \\
130.2849 \\
18.91633 \\
0.000000\end{array}$} & \multirow{6}{*}{\multicolumn{2}{|c|}{$\begin{array}{l}\text { Mean dependent var } \\
\text { S.D. dependent var } \\
\text { Akaike info criterion } \\
\text { Schwarz criterion } \\
\text { Hannan-Quinn criter. } \\
\text { Durbin-Watson stat }\end{array}$}} & 0.368055 \\
\hline & & & & 0.167253 \\
\hline & & & & -2.145697 \\
\hline & & & & -1.546508 \\
\hline & & & & -1.903195 \\
\hline & & & & 1.094032 \\
\hline & & & & \\
\hline
\end{tabular}

The above results indicate that NDEBTTAXSHIELD and BRISK are insignificant because probability value for these variables are larger than 0.05 . On the other hand, TIE is significant at $1 \%$ level of significance.

The $\mathrm{R}$ square value $(0.843864)$ shows that independent variables such as TIE, BRISK and NDEBTTAXSHIELD explained 84.38\% variation in Debt to Equity). The R Square value is greater than 0.50 , therefore, data shows that study model is fit and has good explanatory power. Similarly, F-statistic value (18.91) and its corresponding probability value (0.000) also, indicates that overall model is significant.

On the basis of Table 3 results, following summary of hypothesis tested:

\begin{tabular}{|l|l|l|}
\hline Hypotheses & P-value & Accept / Reject \\
\hline $\mathrm{H}_{1}$ : The TIE has significant impact on capital structure (DER) & 0.0032 & Fail to Reject \\
\hline $\begin{array}{l}\mathrm{H}_{2}: \text { Business risk has significant impact on capital structure } \\
(\mathrm{DER})\end{array}$ & 0.2488 & Reject \\
\hline $\mathrm{H}_{3}:$ The NDTS has significant impact on capital structure (DER) & 0.5877 & Reject \\
\hline
\end{tabular}




\section{DISCUSSION}

The debt servicing has become a major component of Pakistan cement Industry cost as even the decrease by three times in the past one year whereas, the effective bank mark up for this sector is still higher than 12 percent(The Nation, 2017). Meanwhile, managers stressed on the importance of capital structure to manage the company financials which requires detailed analysis from various points of views (Brigham and Ehrhardt, 2013). Company operated through debt and equity but capital structure signifies the importance while defining composition. On the basis of results negative coefficient of TIE indicate the companies are not earning enough to pay off its liabilities. From Creditors point of view negative relation with debt to equity ratio is not positive sign because this increases interest income for lenders. And the companies having weak ratio may face difficulties in raising capital for their operations. The companies having higher interest expense may result a low interest earned and also indicate the advantages and disadvantages associated with comparison over a time (Boyas and Teeter, 2017).

The empirical literature of corporate finance revealed number of potential determinants related to capital structure. The determinants include profitability, potential of growth, firm size, non-debt tax shield, Business risk. Whereas, profitability have negative relation with leverage and volatility or business risk caused potential cost of financial distress and negative impact on leverage (Ferrarini, Hinojales and Scaramozzino, 2017), meanwhile the results of business risk also confirmed the same.

However, the results are confirming that debt has significant impact on determinants of capital structure as well positive debt tax shield with debt to equity ratio. In addition, capital structure has also significant impact on the total amount of cash flows that is available for security holders. The use of debt causes reduction in of outflow for taxes and increases the amount of cash flows for security holders. And resulting tax advantages of debt are balanced with bankruptcy costs if usage of leverage optimal (Dhaene et. al. 2017).

\subsection{Results}

The capital structure is topic which is widely discussed and examined its determinants extensively. Whereas, this study is effort to the addition of knowledge related to business risk involved with cement sector and its financial ability to repaying the debts. Meanwhile, the merit of this study is to elaborate some corporate concepts and theories in context to the cement sector of Pakistan. This paper tries to explore and investigate the hidden facts of corporate finance and translate them in selective cement listed companies while studying their capital structure aspects.

Moreover, the empirical results of paper suggest on the basis of significance that the there is significant impact Time Interest Earned with debt to equity ratio in cement sector. On the basis of literature the increasing demand of cement in domestic market due to "one belt, one road" financed by china spurs construction, and this also caused country's economy has grown at about 5 percent annually since the year 2013 (Bloomberg, 2017). Meanwhile, this growth made cement sector stable otherwise on the facts it is worrisome moment for the 
industry but in longer term declining in exports may have serious ramifications for the innovativeness of industry.

However, the boom in domestic industry creates opportunity and as well requires investments and funds for its operational activities and to pay the debts of companies. For this, the Financial Managers needs to make the important decisions related to continuation of operations and funding decisions. Company operated through debt and equity but capital structure signifies the importance while defining composition. Therefore, on the basis of results companies should be careful while raising the funds through long term debt because it may affect the efficiency and profitability of company. Whereas, making choice of managing the fund sources and laying the capital structure is not an easy decision as it is seen, but, it has the important implications on the future operations. According to study, capital structure is not only affected by tax of the company but income tax is also affected by personal income tax (Miller, 1963).

\subsection{Recommendation}

It is recommended that firms should make effective decisions while raising funds through multiple sources; because, it may face some serious problems if there is significant business risks.

\subsection{Policy Implication}

The capital structure of any firm has significant importance to determine the future growth. Therefore as per this study the volatility and business risk involved in the cement sector may have some serious issues if the exports is continuously decline and at same time raising leverage funds may hurt the performance of company.

\section{REFERENCES}

(2016-2017). Pakistan Economic Survey. Islamabad: Ministry of Finance Pakistan.

All Pakistan Cement Manufacturer Association. (2017, March Monday 12). Retrieved July Sunday, 2017, from apcma: http://www.apcma.com/data_productioncapacity.html

Bloomberg. (2017, May Tuesday). Retrieved July sunday, 2017, from China Boom to Churn Out Pakistan's Largest IPO in Decade: https://www.bloomberg.com/news/articles/2017-05-15/china-building-boom-tochurn-out-pakistan-s-largest-steel-ipo

BMI Research. (2017, April Monday 27). Retrieved July Sunday, 2017, from China's Infrastructure Investment in Pakistan a Win for Both: http://www.bmiresearch.com/articles/chinas-infrastructure-investment-in-pakistan-awin-for-both

Business. (2017, April Friday). Retrieved June Sunday, 2017, from The Express Tribune : https://tribune.com.pk/story/1376638/capacity-utilisation-peaks-cement-sales-soar/

Business Recorder. (2017, April Tuesday). Retrieved July Sunday, 2017, from brecorder: http://www.brecorder.com/2017/04/11/342941/cement-tethered-to-local-demand/

The Nation. (2017, March 11). Retrieved July 8, 2017, from Debt servicing a major part of cement industry cost: http://nation.com.pk/business/11-Mar-2013/debt-servicing-amajor-part-of-cement-industry-cost 
Agnello, L., Castro, V., Jalles , J. T., \& Sousa, R. M. (2014). Do debt crises boost financial reforms? Applied Economics Letters, 22(5), 356-360.

Akerlof, G. .. (1970). The Market for "Lemons": Quality Uncertainty and the Market Mechanism. The Quarterly Journal of Economics, 84((3)), 488-500.

Barakat, M., \& Rao, R. .. (2012). The Role of Taxes in Capital Structure: Evidence from Taxed and Non-taxed Arab Economies. SSRN 2026751.

Boyas, E., \& Teeter, R. (2017). Teaching Financial Ratio Analysis using XBRL. Developments in Business Simulation and Experiential Learning, 44(1), 116-120.

Brigham , E. F., \& Ehrhardt, M. C. (2013). Financial Management: Theory \& Practice. Mason, $\mathrm{OH}:$ : Cengage Learning.

Dhaene, J., Hulle, C. V., Wuyts, G., \& Schoubben, F. (2017). IS THE CAPITAL STRUCTURE LOGIC OF CORPORATE FINANCE APPLICABLE TO INSURERS? REVIEW AND ANALYSIS. Journal of Economic Survaeys, 31(1), 169-189.

Ferrarini , B., Hinojales, M., \& Scaramozzino, P. (2017). Leverage and Capital Structure Determinants of Chinese Listed Companies. Asian Development Bank, 1-33.

Gordon, R. H. (2010). Taxation and corporate use of debt: Implications for tax policy. National Tax Journal, 63((1)), 151-174.

Graham , J. .. (2000). How big are the tax benefits of debt? The Journal of Finance, Vol. 55((5)), 1901-1941.

Huang, G. (2006). The determinants of capital structure: Evidence from China. China Economic Review, 17((1)), 14-36.

Jaggi, B., \& Gul, F. .. (1999). An Analysis of Joint Effects of Investment Opportunity Set, Free Cash Flows and Size on Corporate Debt Policy. Review of Quantitative Finance and Accounting, vol. 12((13)), 371-381.

Kasmir, K. (2012). Analysis laporan keuangan. Jakarta: Raja Grafindo.

Kolay, M., Schallheim, J., \& Wells, K. (2011). Do Non-debt Tax Shields Matter for Debt Policy? University of Utah Working Paper, 1-49.

Marcus, B. M. (2006). Dasar-Dasar Manajemen Keuangan Perusahaan. Edisi, 5(Jilid 2).

Melewar, T. (2008). Facets of Corporate Identity, Communication and Reputation. London: Routledge.

Miller, M. H. (1963). Static-Trade of Theory. Cambridge:: Cambridge University Press.

Princen. (2012). taxes do affect corporate financing decissions: the case of Balgeian ACE.

Qureshi, M. A., Ahsan, T., \& Azid, T. (2017). Equity and Debt Financing Strategies to Fuel Global Business Operations During Crisis. Istanbul: Springer.

Ross , S. A. (1977). The determination of financial structure: The incentive-signalling approach. The Bell Journal of Economics, 8((1)), 23-40.

Sahudin, Z., Mehmood, W., Ismail, F., Paradi, F., Aziz, A., \& Sahudin, M. (2011). Debt structure for Malaysian construction companies: Evidence from panel data analysis. Management, 1(3), 1-7.

Salawu, R. O., \& Agboola, A. A. (2008). The determinants of capital structure of large nonfinancial listed firms in Nigeria. The International Journal of Business and Finance Research, 2((2)), 57-84.

Sawir, A. (2008). Analisis Kinerja Keuangan dan Perencanaan Keuangan. Jakarta: PT. Gramedia Pustaka Utama.

Sawir, A. (2008). Analisis kinerja keuangan dan perencanaan keuangan perusahaan. Jakarta: Gramedia Pustaka Utama.

Song, H. S. (2005). Capital Structure Determinants an Empirical Study of Swedish Companies. Stokholm: Royal Institute of Technology.

Spence, M. (1973). Job market signaling. The Quarterly Journal of Economics, 4, 355-374. 
Sung, T., \& Kim, D. (2017). How chaebol restructuring after the 1997 crisis has affected corporate decision and performance in Korea: debt financing, ownership structure, and investment. China Economic Journal, 10(2), 147-161.

Suratno, Djaddang, S., \& Ghozali, I. (2017). The Role of Business Risk and Non Debt Tax Shields to Debt to Equity Ratio on Pharmacy Listed Companies in Indonesia. International Journal of Economics and Financial Issues, Vol.7(2), 73-80. 